Научна грађа

УДК 821.163.41.09-95 Олујић Г. 050.486:82МЛАДАКУЛТУРА“1952/1957“

Примљен: 28. фебруара 2021.

Прихваћен: 6. априла 2021. https://doi.org/10.46630/phm.13.2021.60

Катарина С. Миленковић ${ }^{1}$

Универзитет у Нишу

Филозофски факултет

Мастер академске студије филологије

Александра С. Пејић

Универзитет у Нишу

Филозофски факултет

Мастер академске студије филологије

\title{
КРИТИЧКИ ПОЧЕЦИ ГРОЗДАНЕ ОЛУЈИТ У ЧАСОПИСУ МЛАДА КУЛТУРА
}

Циљ овог рада је осветљавање недовољно истраженог подручја рада Гроздане Олујић, које се односи на њена прва књижевнокритичка остварења. Зачетке њеног есејистичког и књижевнокритичког рада налазимо у часопису Млада култура који је излазио у периоду од 13. новембра 1952. до 6. јуна 1957. године. У раду се разматрају замеци књижевне критике заступљене у овом часопису, у периоду када је ова књижевница имала око двадесет година. Гроздана Олујић инклинира импресионистичкој критици кроз целокупан стваралачко-критички рад у часопису Млада култура. Рад прати сазревање Гроздане Олујић као књижевног критичара, као и утицај који је часопис Млада култура имао на формирање њених методолошко-критичких ставова.

Кључне речи: Гроздана Олујић, књижевна критика, есеј, часопис Млада култура

\section{1. Млада култура као омладински гласник}

У књижевнокритичком животу половином 20. века улогу гласника преузима омладина која је уједно и циљна група новонасталих часописа, међу којима је најутицајнији био Млада култура. Часопис Млада култура јавља се у послератно доба, тачније у првој деценији након Другог светског рата. Бави се уметношћу, а у оквиру ње превасходно књижевношћу. Уредници и дописници Младе културе, највећим делом двадесетогодишњаци, промишљају и пишу о културном аспекту тада-

1 kalemilenkovic7@gmail.com 
шње друштвене ситуације. Први број часописа изашао је 13. новембра 1952. године у Београду. Часопис је излазио сваког другог четвртка уз повремене паузе углавном изазване финансијским потешкоћама, у издању Новинског издавачког предузећа „Омладина”. Подстакнути овим омладинским часописом, све већи број младих читалаца осећа потребу за изражавањем својих критичких ставова. Млади писци који тек ступају на књижевну сцену у том периоду углавном почињу да се баве и књижевнокритичким радом, те задиру у неоткривене потенцијале новонасталих књижевних дела, али и класика светске књижевности. Чак и они писци који се не изјашњавају као књижевни критичари добијају потребу да свој суд поделе са широм јавности. То је случај и са Грозданом Олујић чије књижевнокритичке почетке налазимо управо у поменутом гласилу. Иновативност у проучавању књижевних дела била је приоритет тадашњих књижевних аналитичара. Кроз тумачење конкретних дела проучаваоци књижевности расправљају о методама и циљевима ове уметности који су условљени актуелним социјално-културним дешавањима.

Говорећи о идеји за настанак часописа Млада култура један од уредника, Бора Ћосић, открива да се једне летње вечери окупила група књижевних истомишљеника који су имали жељу да своје књижевне ставове и погледе на књижевност преточе у часопис, који би на подесан начин обухватио духовне вредности и културна тежишта. Првобитна замисао била је да часопис носи назив Сусрети. Међутим, због финансијских потешкоћа, које су онемогућавале остваривање полетних књижевних циљева младих аутора, долази до удруживања два књижевна табора који функционишу под једним називом - Млада култура. Наиме, у то време се појављује још једна група критичара са сличним идејама и књижевнокритичким промишљањима, те се проналази заједничко решење да се књижевне тенденције отелотворе у једном периодичком остварењу. ${ }^{2}$ Сарадници часописа Млада култура биле су личности од изузетне 2 У првом броју часописа уредници су били: Петар Андрић, Иван Ивањи, Младен Ољача, Бора Ћосић, а одговорни уредник био је Славко Вукосављевић. Временом се мењала постава редакције овог часописа. Неки уредници су одлазили или су били избачени, али појављивала су се и нова лица у улози уредника. Из петог броја часописа „Млада култура“ искључен је Бора Ћосић, а Младен Ољача и Иван Ивањи тада сами напуштају редакцију. У осмом броју уредништву, које тада чине Петар Андрић и Славко Вукосављевић, прикључује се и Лаза Лазић. Од десетог броја као уредници јављају се и Драгослав Грбић, Предраг Палавестра и Светислав Мандић, кога већ у четрнаестом броју нема на списку уредника.У 25. броју Драгослав Грбић више није један од уредника, али сада се уредништву прикључио Првољуб Пејатовић. Од 34 . броја главни уредник је Предраг Палавестра, а одговорни уредник и даље је Славко Вукосављевић и тако је до 46. броја часописа. Од 46. па до последњег броја часописа уредници су Милош Бандић, Жика Лазић док Предраг Палавестра напушта уредништво након 53. броја. Од 46. броја па све до краја одговорни уредник је Младен Ољача. У последњим бројевима часописа, тачније од броја 58. до краја, технички уредник овог часописа је Зоран Пауновић. По- 
важности не само за књижевност већ за целокупну српску културу. На списку тих личности налазе се: Иво Андрић, Мирослав Антић, Светлана Велмар-Јанковић, Владета Јеротић, Иван Лалић, Десанка Максимовић, Бранко В. Радичевић, Александар Тишма, Бранко Ћопић, Добрица Ћосић, Павле Угринов, Александар Вучо, Видо Латковић, Петар Џаџић и др.

\section{2. Рубрике часописа Млада култура}

Часопис Млада култура је у време послератне књижевности, као истакнути часопис за књижевност и културу, представљао упориште моралних и културних вредности нове државе. Уредници нису само имали у виду старије писце доказаних квалитета, већ су радо у састав рубрика укључивали и нове младе писце и на тај начин бодрили њихове почетке. Намењен омладини као циљној читалачкој публици, часопис је имао за задатак да оствари и својеврсне дидактичко-васпитне мере кроз презентовање књижевно-уметничких текстова са позитивном васпитном усмереношћу. Осим књижевности, у сваком броју заступљени су и прегледи других врста уметности, као што су сликарство, музика, позориште и филм. Свеобухватност тема којој су уредници тежили огледа се у великој разноврсности и бројности рубрика које се никада заправо нису ни усталиле, већ су се мењале из броја у број и својом флексибилношћу дозвољавале уношење нових тема и садржаја, без ограничавања на одређени шаблонски систем.

Рубрика која је обележила једну од главних оријентација часописа - родољубље, носи назив „Литература и отаџбина”. У складу са тадашњом друштвено-политичком ситуацијом било је неопходно постојање чланака који би на ненаметљив начин бодрили дух и подизали свест народа после рата. Ова рубрика је стога обележена бројним родољубивим поетским начелима која се износе имплицитно, кроз књижевно-уметничка дела, поезију и прозу, као и експлицитно, у виду књижевнокритичких текстова. Намењена првенствено младима, оваква литература обликовала је њихову свест у смеру иманентног напретка и окретања књизи као средству хуманизације друштва.

Учестале рубрике које су се смењивале кроз године издавања часописа тицале су се есеја, трибине, сусрета, кратких културних вести, најава позоришних представа, концерата, изложби, филмских премијера и нових књига, као и кратких приказа, утисака и препорука за читање, посети позоришту, опери или изложби. Осим тога значајан део посвећен је и проучавању наставе у школи, могућим начинима унапређивања и побољшавања система предавања и учења. У једном тренутку уредници

следњи број часописа, заправо двоброј 60-61, излази 6. јуна 1957. године. 
су одлучили и да у часопис унесу приказе писаца обухваћених наставним програмом и на тај начин уведу часопис као помоћну школску литературу која би функционисала као додатак уџбеницима и била од користи ученицима који су представљали већи део читалачке публике.

Значајан сегмент чинили су наградни књижевни конкурси, а од броја 34 отвара се и нова рубрика „Из ђачких свески” која представља мали литерарни скуп младих талената. Тако да су у часопису „Млада култура” своју шансу добили многи млади, до тада неафирмисани аутори попут: Ивана Лалића, Мире Алечковић, Владимира Назора, Милована Данојлића, Владете Јеротића, Петра Гудеља, Бранка Узелца, Душана Матића, Божидара Тимотијевића, Јована Христића, Жике Лазића, Мирослава Антића, Светлане Велмар-Јанковић и многих других. Такође, у часопису Млада култура своје књижевноуметничке текстове објављивила је и Гроздана Олујић. У двоброју 42-43 који је изашао у фебруару 1956. године, појавила се кратка прича Гроздане Олујић Киша је имала меке дланове, а у броју 59. из маја 1957. објављен је одломак њене Мочваре. Многи књижевници тога доба писали су и књижевнокритичке текстове, али и већи део уредништва часописа је, поред бројних критичких текстова, писао и књижевне текстове. На том списку аутора лепе књижевности налазе се и: Петар Андрић, Лаза Лазић, Бора Ћосић и Драгослав Грбић.

Спровођене су и бројне анкете чији су резултати обајвљивани у следећем броју. ${ }^{3}$ Осим тога, објављиване су и преписке и одговори уредништва на поједина писма. Посебан део посвећен је и речи уредника који упознају читаоце са настанком, променама и потешкоћама кроз које је часопис пролазио кроз године објављивања. Такође је важно напоменути да је часопис обогаћен сликама познатих српских и страних уметника који су се јављали као својеврсно употпуњење књижевно-уметничких текстова. Објављивани су ликовни прилози следећих уметника: Франциска Гоје, Надежде Петровић, Уроша Предића, Александра Зарина, Бошка Карановића, Васе Поморишца, Саве Николића и других.

Дакле, уредници Младе културе имали су за циљ приближавање целокупне уметности читалачкој публици. Обогаћивање часописа уметничким сликама, приказима позоришних, филмских и оперских премијера, приказује тежњу уредника часописа ка постизању синкретичости у виду својеврсне културне панораме на којој hе се смењивати уметности.

За омладински часопис Млада култура карактеристична је изузетна разноврсност књижевнокритичких прилога, те се јављају: рецензиje, прикази, памфлети, панегирици, филолошке критике, као и импресионистичке критике, а најчешће су то хибридне творевине са превлашћу 3 Једна од најзанимљивијих анкета која је објављена у часопису Млада култура јесте скуп одговора многих књижевника и љубитеља књижевности на питање: „Којих десет дела послератне југословенске књижевности сматрате најбољим?” 
једне подврсте, или са одликама већине других књижевнокритичких облика. Јавља се како текућа критика, тако и критика већ афирмисаних књижевних дела, класика српске књижевности. Осим поменутих подврста, јавља се и посебан облик књижевне критике - метакритика, тј. критика критике која представља један од пресудних чинилаца у рецепцији књижевног дела код читалачке публике. У Младој култури јављају се и многобројне анкете које имају за циљ вредновање и процењивање књижевних дела. Још један вид књижевног вредновања јесу књижевне награде и књижевни конкурси који су се јављали спорадично у овом омладинском часопису и отварали могућност младим талентима да се остваре као писци. Књижевни конкурси представљају најбољи облик вредновања необјављене прозе младих аутора.

\section{3. Критички рад Гроздане Олујић у часопису Млада култура}

Књижевнокритички текстови Гроздане Олујић које проналазимо у часопису Млада култура припадају самим критичким почецима ове књижевнице. Иако је своје текстове слала као веома млади дописник часописа, критике Гроздане Олујић су веома зрела поетичко-научна остварења. Она коментарише текућу књижевност експлицитно износећи своје етичке и естетичке норме и књижевна начела којима се руководи.

Прилози Гроздане Олујић у часопису Млада култура припадају различитим видовима књижевне критике. Листајући часопис наилазимо на панегирике, где је доминантан позитиван став аутора према писцу или делу. Неки од текстова дати су у виду краћих књижевних приказа. Иако не у целости, већина текстова које Олујић пише, осврћући се на текућа књижевна остварења, има елементе филолошке критике. Мада о делима које је изабрала за предмет критике Гроздана Олујић има позитиван став, могу се наћи и памфлети, критике у којима је експлицитно дато негативано мишљење аутора. Олујић пише и рецензије у којима даје „преглед и процену вредности рукописа и текстовног материјала” (ŽIVKOVIĆ 1986: 634). С обзиром на то да су дела о којима пише Гроздана Олујић углавном настајала непосредно пре објављивања прилога у часопису, може се закључити да су у питању текуће критике.

Гроздана Олујић у часопису Млада култура објављује и разговоре које је водила са познатим уметницима тог периода. Неки од њих су мањег, а неки већег обима, али свакако ваља напоменути оне најзначајније, а то су разговори са Исидором Секулић и Душаном Матићем. У већини својих текстова Олујић се дотиче истих елемената и остаје верна својим поетичким мерилима.

У критичким текстовима Гроздане Олујић хронолошки су за- 
ступљени следећи аутори: Мбон Оџајк, Франсоаз Сагон, Михајло Коцјубински, Исидора Секулић, Владан Десница, Павле Угринов, Мира Алечковић, Фрида Филиповић, Војислав Кузмановић, Душан Матић, Бранко В. Радичевић, Бошко Петровић, Воја Царић, Радомир Константиновић, Флорика Штефан, Нада Маринковић и Светлана Велмар Јанковић.

\section{1. Моја Африка и Добар дан туго}

У 34. броју часописа Млада култура (15. септембар 1955) налазимо прва два књижевнокритичка текста Гроздане Олујић: Моја Африка и Добар дан туго.

Моја Африка је рецензија књиге Мбона Оџајка, нигеријског политичара, коју можемо сматрати својеврсном монографијом посвећеном отаџбини аутора. Гроздана Олујић истиче да Мбон Оџајк Африку посматра кроз време, указујући нам на то како је она изгледала некад, а како изгледа данас, након продора утицаја западних земаља. Како Олујић наводи у свом делу, Оџајк се првенствено бави уметношћу и месту које она заузима у животу афричког човека. Напомиње се да је сколност ка уметничком изражавању кроз разне медијуме дубоко урезана у свест његовог народа и представља битан део сваког појединца. Гроздана Олујић упућује на ауторову мисао да је целокупна уметност која се ствара на „црном континету” у потпуности инвентивна и да нема подражавања међу уметницима. Осим на књижевност, Олујић се осврће на сликарство и вајарство, о којима Оџајк пише, пратећи њихову развојну линију, и на тај начин глорификује уметност у целости. Такође, неизбежан је и осврт на социјално-политичку ситуацију родне земље аутора. Овим кратким књижевним приказом Гроздана Олујић нам показује колико је уметност важна за развој једне цивилизације, али и за свакодневни живот човека. Стављање уметности у тај положај представља својеврстан кључ за проучавање методолошко-аналитичких ставова Гроздане Олујић.

Друга критика коју Гроздана Олујић објављује у часопису Млада култура посвећена је изузетно младој француској књижевници Франсоаз Сагон и њеном роману Добар дан туго. Може се уочити велика генерацијска блискост ове две ауторке. Наиме, Гроздана Олујић у тренутку кад пише овај текст има 21 годину, док је ауторка романа на који се критика односи две године млађа. Олујић помиње полемике које је ово дело изазвало у тадашњој француској књижевној јавности и истиче да је дошло до огромног мимоилажења у ставовима тамошњих проучавалаца књижевности, с обзиром на то да су критичка мишљења о овом роману била подељена на два, у потпуности супротна дела. Једни су истицали генијалност ове младе деветнаестогодишње ауторке, док су се други о њеном делу изјашњавали као о дегенерисаном и безвредном књижевном 
покушају. Олујић (1955: 6), међутим, сматра да је у питању: „само вешто написана прича инспирисана животом француских виших кругова”. Као позадину настајања овог романа она наводи друштвену ситуацију, те истиче да „овај мали цинични роман ипак (мада несвесно) даје критику живота француских аристократских кругова и једног морала који са моралом ничег заједничког - нема." (OLUJIĆ 1955: 6) Закључујемо да овај текст Гроздане Олујић представља рецензију романа сагледаног са објективног гледишта, где су наведени и недостаци и предности уметничког остварења младе књижевнице.

\section{2. Фатаморгана; Рад, самоће и ћутана}

Гроздана Олујић критички се осврће и на украјинску литературу у броју 35 из 29. септембра 1955. У кратком приказу стваралаштва украјинског аутора Михајла Коцјубинског, пре свега његове књиге Фатаморгана ауторка излистава основне одлике његове прозе и као позитивне карактеристике наводи реалистичност у приказивању људских судбина, као и аутентичност ликова. Приказ је написан у краткој форми која изгледа недовршено, те је могуће да је написан у циљу интригирања читалаца да сами прочитају дело и сазнају где ће их одвести назнаке које је Гроздана Олујић само споменула.

Четврта критика Гроздане Олујић у Младој култури јесте књИжевни разговор са Исидором Секулић, објављен у 36. броју часописа који је изашао 13. октобра 1955. године. У овом поетски интерпретираном интервјуу видљиви су елементи позитивистичке критике. Наиме, у тумачење дела Исидоре Секулић, Гроздана Олујић учитава и њену биографију. Сматра да је готово незаобилазно осврнути се на сензибилитет и темперамент ауторке која је скоро читав живот провела у самоћи. У једном сегменту разговора и сама Исидора Секулић (1955: 1) истиче да на њена дела умногоме утичу личности из окружења у коме је одрастала: „Мене је васпитавао мушкарац, отац, каже. А то је оставило трага на моме карактеру и стваралаштву.” У том контексту Гроздана Олујић издваја следеће аутопоетичке ставове Исидоре Секулић (1955: 1):

„Ми никада нисмо имали времена да мирно изграђујемо своју културу. Ратови, збегови, лутања, разарања и грађења на рушевинама - то је наша историја. Па и онда када смо стварали све је ишло вртоглавом брзином - сламало је људе. Ми никада нисмо имали више од три генерације интелектуалаца" (OLUJIĆ 1955: 1).

Разговор који су водиле две књижевнице обухватао је широко поље тадашње културне и социјалне стварности, уз историјски осврт на 
минуле ратне године. Ове две за нашу књижевност веома значајне списатељице, дотичу се различитих проблема тадашњег човека и разговарају о односу талента и неуморног рада као два међусобно неискључива аспекта у процесу рађања уметничког дела.

Стил којим се Гроздана Олујић служи при приказивању других дела одликује се изразитом субјективношћу и доминацијом личних доживљаја. Гроздана Олујић је добар пример писца који књижевну критику представио као вид уметности речи.

Тумачење књижевних дела кроз изразито лични доживљај такође је карактеристичан поступак Гроздане Олујић. У том смислу, у тексту Рад, самоће и ћутања уочљиви су елементи импресионистичке критике. На хетерогеност критике Гроздане Олујић реферише нам и чињеница да се она осврће и на језик и стил Исидоре Секулић. Говорећи о језику којим се служи Исидора Секулић, Олујић (1955: 1) истиче следеће: „Реч је концизна, скоро шкрта, а ипак крцата великим мислима које налазимо у њеним есејима о језику, о Његошу, у Писмима из Норвешке, у Хрониии паланачког гробла."

\section{3. Приморско пролеће}

Критика збирке приповедака Владана Деснице Прољеће у Бадровцу објављена је у броју 37 Младе културе (2. октобра 1955. године). У овом тексту, Гроздана Олујић износи промишљања о међулитерарним утицајима и књижевним претходницима тако што за литерарне претке Деснице издваја Симу Матавуља и Ива Ћипика. Као највећу вредност збирке Владана Деснице Олујићева износи унверзалност тема које он обрађује. Како ауторка наводи, Десница у својим приповеткама обрађује свакодневне проблеме обичних, малих, ненаметљивих људи са којима се свако од нас може идентификовати. Кроз обраду појединости из живота Десница исказује најдубље животне истине, а то би, по мишљењу Гроздане Олујић, требало да буде императив савременог писања. Тумачећи Десничин начин мотивације поступака ликова и њихове психологизације кроз ћутање, Олујићева наводи објективност као квалитет прозних остварења Владана Деснице. С обзиром на то да ова критика има одлике панегирика, можемо закључити да Гроздана Олујић вредним сматра иста, како етичка тако и поетичка, начела као и Владан Десница. Стоицизам којим се одликују јунаци Владана Деснице за Гроздану Олујић чине битну моралну карактеристику сваког појединца. Можемо закључити да су критеријуми Гроздане Олујић при вредновању збирке Прољеће у Баmровиу на тематском плану универзалност и ванвременска актуелност проблема, истицање моралних норми, као и приказивање животних вредности у окриљу свакодневице. 


\section{4. Бачка запевка}

Шеста критика Гроздане Олујић на коју наилазимо у часопису јесте рецензија збирке Бачка запевка Павла Угринова. Ова критика објављена је у 37. броју часописа Млада култура који је изашао 27. октобра 1955. године.

Након критика у којима се бави прозним делима, Гроздана Олујић овај текст посвећује поезији. На самом почетку истиче да је Војводина, после Богдана Чаплића и Мирослава Антића, добила још једног великог савременог песника. Иако напомиње да збирка има недостатке, крајњи суд Гроздане Олујић (1955: 6) је позитиван:

„Само, питамо се понекад, не квари ли обиље тих имена и израза поезију ове књиге, не разводњава ли је помало, не успорава ли њен ритам који се, од прича о судбинама појединаца (Теодора, Никанора Воденог Коња, Исаије), убрзава да би у циклусу Тиса се улива у Дунав (песма „О Војводино”) већ самом снагом свог замаха изразио бол нашу равничарску, панонску, не олакшава ли тежину једне књиге, која је без обзира на местимичне падове - успела" (OLUJIĆ 1955: 6).

У проматрању дела овог аутора уочљиви су елементи и филолошке критике. Гроздана Олујић наглашава да је језик поезије Павла Угринова у функцији карактеризације ликова, те да на тај начин овај млади песник своје јунаке изграђује врло успешно. Употреба локалних израза додатно осветљава одређене сегменте карактера књижевних ликова и има улогу њихове психологизације. Кроз говор јунака, али и уношење прозних елемената у поезију, Угринов жели да дочара атмосферу Војводине, и то му, како истиче Олујићева, и успева. Међутим, ауторка поставља и питање не квари ли толика прозаизација збирку Бачка запевка. Наглашава значај ритма и форме као суштинског обележја поезије, које се уношењем прозних сегмената знатно нарушава. Један део критике посвећен је и формалном аспекту, те се Гроздана Олујић осврће на версификацију и структуру песама, напомињући значај „фактуре стиха”.

\section{5. Страх и човечност}

Следећи текст Гроздане Олујић који је објављен у часопису Млада култура јесте критика романа Зашто грдиш реку Мире Алечковић. Објављена је у двоброју 42-43, из фебруара 1956. Ово је још једна критика у којој Гроздана Олујић на изразито поетски начин износи своје погледе на књижевност. У већини критика Гроздане Олујић, па тако и у овој, долази до прожимања уметности и науке.

Ауторка износи позитиван став о роману Зашто грдиш реку, 
али и о целоупном дотадашњем стваралаштву Мире Алечковић. Такође, битно је напоменути да Гроздана Олујић, иако не експлицитно, говори о „женском писању”. Ненаметљиво, али ипак ефектно, пишући о многим женама писцима, Гроздана Олујић доприноси афирмацији жена као аутора лепе књижевности.

Олујић излаже хронотоп, односно место и време у којима се одиграва радња романа. Такође, један део критике посвећује и језику којим је роман написан, тако да и ту можемо уочити одлике филолошке критике. О реченици Мире Алечковић, Гроздана Олујић каже да је брза, истрзана, темпераментна. Управо та динамичност у изразу повезује овај роман Мире Алечковић са авангардним романима. У таквим остварењима учестала су и набрајања, а скоро увек тема је рат. Осим тога, већина авангардних романа, а то је случај и са романом Мире Алечковић, нема главног јунака. Тешка судбина, патње и бол народа након рата превише су велики да би се представили само кроз једног човек, истиче критичарка. Стога би у овом роману улогу главног лика могао преузети целокупан српски народ. Представљање колектива као јунака коме је посвећено готово цело дело, такође је одлика авангардне прозе. Олујићева напомиње да се у овом роману може уочити и много драмских елемената, те да је ово дело тешко сврстати у један жанр, што нам директно сведочи о хибридности жанрова.

Дакле, овом прозном остварењу Мире Алечковић дата је не само критика, већ и интерпретација романа. Говори се о теми дела, као и о друштвено-политичкој ситуацији која је утицала на његово настајање. Главна тема овог романа је рат, те је један део критике посвећен управо послератној поетици. Као што се и насловом критике имплицира, страх заузима битно место у роману Мире Алечковић:

„Јер код Алечковићеве, то није страх пред животом и од живота, већ за живот. За ову земљу која у себи не може да трпи чак ни кости издајника, која је мала и убога, разапета између пушке и плуга, црна од туге и бела од костију своје деце, сва пркос и понос, сва легенда о страху који је био љубав и постајао храброст " (OLUJIĆ 1956: 5).

Кроз наведени цитат може се доста тога закључити и о социјално-културној ситуацији у којој се налази отаџбина списатељице. Експлицитно су представљене друштвене норме и етичка начела тога периода. Рат, као и последице које он за собом оставља, формирају друштво које је огорчено и недовољно способно да у свакодневици пронађе било шта вредно. Из тог разлога, књижевност треба да буде та која бодри и подстиче народ на трагање за бољим сутра, као и за извлачењем каквих год позитивних страна пређашњег периода. С обзиром на то да је у оквиру 
читалачке публике Младе културе велики број младих који, рођени за време или после рата, не виде позитивне аспекте живота, критика има за циљ подизање воље народа. Закључујемо да тумачећи текућа књижевна остварења, Гроздана Олујић износи своје хуманистичке ставове и етичке норме.

\section{6. Поезија свакидашьице и Птице без јата}

У 45. броју часописа проналазимо још једну критику посвећену „женском писању”. У броју изашлом 13. маја 1956. године налази се текућа критика Поезија свакидашњьце коју Гроздана Олујић упућује збирци приповедака Фриде Филиповић До данас. Ова збирка изашла је из штампе исте, 1956. године и обрађује свакодневну тематику, а проблеми јунака могу се посматрати као проблеми свакога од нас. Ту на делу проналазимо универзалност књижевности, коју Гроздана Олујић доживљава као суштинску особину читаве уметности. Иако напомиње да збирка До данас не доноси ништа ново ни на плану садржине ни на плану форме, крајњи суд према овој збирци је изразито позитиван.

Посматрано кроз шири контекст, може се приметити сличност у темама које обрађују ове атуорке. Наиме, каснији романи Гроздане Олујић имају сличну поетику као и приповетке Фриде Филиповић, о којима она износи своје књижевно-поетичке ставове. Односно, мали свакодневни јунаци представљају стожер и у делима Гроздане Олујић. Такође, сличност је и у постављању жене као главног лика дела, као и веома истанчана психологија јунакиња. Збирка приповедака Фриде Филиповић је ванвременска и ванпросторна како то наглашава Гроздана Олујић. Та универзалност, по мишљењу критичарке, требало би да представља најзначајнију тежњу књижевности.

Један део написа посвећен је стилу и језику приповедака. Истиче се да је реченица Фриде Филиповић лака и гипка, као и то да нема неочекиваних обрта ни у реченици ни у композицији. Гроздана Олујић (1956: 6) напомиње и да су приповетке драматизоване, као и да у самој збирци има „много топлине, и поезије ситних, обичних ствари.” И у овој критици Гроздана Олујић остаје верна свом поетском изразу приликом тумачења уметничких текстова.

Још једна критика Гроздане Олујић објављена у истом, 45. броју часописа Млада култура приказ је збирке приповедака Војислава Кузмановића Петар у пјеску. Ово је текућа критика с назнакама памфлета. Иако нас почетак критике подсећа на панегирик, Гроздана Олујић своје хвале овој збирци ограничава само на форму, додајући да, сем добре форме и веште употребе језика и реченице, у овој збирци нема других позитивних тачака. Олујић (1956: 6) износи негативне стране највише на 
плану тематике, као и погледа на свет, како аутора тако и његових јунака.

„Али, осим те формалне постоји још једна (далеко важнија) - садржинска компонента која у себи обавезно носи овај или онај вид уметничке истине. Војислав Кузмановић има своју истину и све би било у реду када би та истина могла да буде и НАША. Али, није тако. Декомпоновани, морбидни свет његових јунака померених савести не можемо да прихватимо као свој” (OLUJIĆ 1956: 6).

Олујић својим текстом скреће пажњу на песников деградирајући песимизам и цинизам. Истиче неукорењеност Кузмановићевих јунака, чији је поглед на свет сужен и чија размишљања често прелазе у хладни и равнодушни нихилизам. Јунаци ових приповедака су птице без јата, не могу се укоренити, а смањена им је и могућност идентификације са било чим ван тог песимистичног круга у који су затворени. То није оно што је потребно народу који се тек опоравља од немерљивих губитака које је рат донео. Ова критичарка књижевност види као нешто што треба да бодри и подстиче људе на проналажење доброте и оптимизма у свету који их окружује, али и у оном свету који је у њима самима. Дела која настају у том тренутку требало би да наметну трагање за апсолутом које је непрекидно и неуморно. Стога, књижевност треба да буде универзална, свељудска и свевремена, да изражава оно што је бит човековог постојања, а приповетке Војислава Кузмановића које дезинтегришу човека, његово постојање, свет који га окружује и патриотизам, свакако то нису. Гроздана Олујић на врло експлицитан, скерлићевски начин негодује због тог песимизма који разграђује не само човека већ и велики таленат младића који свет посматра на такав начин. На самом крају она износи жаљење што „овај млади писац није нашао светлије тонове и човечније истине” (OLUJIĆ 1955: 6).

\section{7. Вечита свежина света}

Књижевни разговор који је Гроздана Олујић водила са Душаном Матићем објављен је у двоброју 49-50 Младе културе који је изашао 9. августа 1956. године. У разговору са еминентним авангардним уметником Гроздана Олујић дотиче се општих питања литературе и целокупне уметности, као и односа младих према савременим културним дешавањима. Читав разговор вођен је у циљу расветљавања проблематике заступљене у књижевном стваралаштву Душана Матића и његових савременика.

На самом почетку разговора, поређењем Душана Матића са Cepгејем Јесењиним ауторка наглашава аутобиографску црту која се уочава у делима и једног и другог ствараоца. Питања Гроздане Олујић отварају могућност за позитивистички приступ тумачењу Матићевих дела који се 
заснивао на томе да открије да постоји „каузална веза између пишчеве биографије (склоности, морала, преокупација, кључних догађаја из живота), с једне стране, а с друге, форме и значења књижевног остварења" (POPOVIĆ 2007: 92). Сам Душан Матић у одговору на једно од питања, на неки начин, потврђује да је у Багдалу унео део свог живота.

Кроз књижевни дијалог разматрају се и питања универзалних проблема човека који се налази у дезинтегрисаном свету као последици рата. Разговор покрива вечите теме са уплитањем у политичку ситуацију и обесмишљеност социјално-моралних норми које остају након рата. Свевременост тема које обрађују јесте одлика поетике како Душана Матића тако и Гроздане Олујић, а писање о универзалним проблемима је императив ово двоје аутора.

Због великог броја отворених тема, овај разговор представља изузетан допринос проучавању књижевности и формирању књижевно-уметничког укуса младих половином 20.века. Душан Матић истиче разноликост као императив књижевности уопште. Разматра се иновативност кроз дијахроно проматрање књижевнх текстова, даје се осврт на однос младих према уметности, а посебно је интерпретирано и питање о условљености књижевности, односно утицај стране литературе на на нашу књижевност као и питање интратекстуалности. У овом одговору са Душаном Матићем проналазимо чврст и јасан став да књижевност најбоље разумеју они који је и стварају, те би се критички рад Гроздане Олујић која у то време и сама почиње да пише и лепу књижевност, могао сматрати меродавним и веродостојним. Дакле, критикујући књижевност, Гроздана Олујић поставља стваралачке темеље своје будуће литерарне оријентације.

\section{8. Нова збирка песама Бранка В. Радичевића}

Гроздана Олујић се враћа критици поезије у Младој култури текстом објављеним 4. фебруара 1957, у броју 52. У њему износи позитиван суд не само о последњој збирци песама Бранка В. Радичевича Вечита пешадија, већ се осврће на његов целокупни рад (претходну збирка $3 e-$ мља), истичући вредност целокупног песничког рада Бранка В. Радичевића. При помињању претходне збирке наглашава се изузетан напредак у поетском изразу овог песника, те на тај начин ауторка прати његово уметничко сазревање. Гроздана Олујић хвали версификацијско освежење које се јавља у нашој поезији са новом збирком овог младог песника. У складу са својим поетским начелима и књижевнокритичким критеријумима Гроздана Олујић (1957: 4) хвали универзалност тема које у својој поезији обрађује песник Бранко В. Радичевић: „И ту се песникова мисао смело рве с проблематиком завичајног и људског, али сад проширених 
видика, често инклинира ванвременском и општељудском” (OLUJIĆ 1957: 4).

Као једину слабост нове Радичевићеве збирке Олујићева наводи пад естетске вредности појединих песама нарочито истичући „Ледену поему”, али не залази у дубљу проблематику поменутих недостатака. Отуда ову критику и даље можемо посматрати као својеврсну похвалу свежини и оригиналности збирке, као и њене сугестивности и језика у форми смелих инвентивних стихова.

\section{9. Боје свога неба и Чудесни свет детиюства}

У рубрици „Сусрети” 53. броја часописа Млада култура објављеног 28. фебруара 1957. наново се срећемо са кратким књижевним дијалогом који Гроздана Олујић овог пута води са Бошком Петровићем, добитником награде „Матице Српске” за књигу Лагано промичу облаци која је према речима Гроздане Олујић (1957: 1) „у срж војвођанска, не само садржајно-тематски, но и композиционо-стилски”.

Олујић (1957: 1) се у уводу задржава на повезаности тематике и језичке организованости овог романа и закључује да је Петровић чак и „фактуру своје реченице прилагодио разливеном и успореном говору војвођанског сељака”. Истичући ту чињеницу као поступак постизања изворности и уверљивости текста, Гроздана Олујић наглашава да је то предност, а не недостатак овог романа, што је био став тадашње књижевне критике.

Кроз разговор са писцем провлачи се својеврсна критика савремене књижевности од стране Бошка Петровића, а пре свега војвођанске литературе. Он наводи поједине, по његовом мишљењу, значајне младе војвођанске писце: Флорику Штефан, Мирослава Антића, Поповића, Милина, Маркова и Бискупљанина. Као и у целокупном раду и овде уочавамо извесну наклоњеност Гроздане Олујић завичајној литератури. Војвођански писци су углавном предмет њене похвале.

У овом броју часописа Млада култура објављен је и књижевни разговор Гроздане Олујић са једним од ретких писаца за децу тога доба, Војом Царићем. На почетку критике Чудесни свет детиюства покреће се тема општег стања тадашње српске литературе, а пре свега промена тока књижевности где се писци све више ослобађају шаблонизиране књижевности и фактографије у корист апстракције и иреалности.

Разговор се наставља у правцу анализирања ситуације у којој се налази тадашња књижевност за децу. Учесници књижевног разговора деле мишљење о неоправданој запостављености овог дела књижевности. Стагнација литературе за децу у послератном периоду је очигледна, а у 
прилог томе сведочи чињеница да књижевна награда „Невен”, која се односи управо на остварења посвећена најмлађима, те године уопште није додељена. Разматра се дидактичко-васпитна функција књижевности намењене деци, као и сложеност и неисцрност могућности у писању литературе за најмлађе. То се и износи као један од разлога што тако мали број писаца одлучује да се посвети том задатку.

Двоје српских књижевника завршава разговор полемишући о односу књижевне критике према књижевности за децу. На питање како књижевна критика оцењује и вреднује литературу намењену деци, Воја Царић одговара: „Она се тиме скоро уопште не бави. Од шездесет књига које годишње изађу прикаже се највише четири-пет, па и то најчешће у два-три листа" (OLUJIĆ 1957: 1).

Можемо закључити да ова врста новинарског ангажовања Гроздане Олујић умногоме утиче на формирање њених поетичких начела и критичких критеријума. У своја потоња дела она инкорпорира искуства понета из дијалога вођених са разним афирмисаним ауторима, а од писаца чија дела критикује и на чији се рад осврће, углавном ствара сопствене књижевне узоре. Целокупни журналистичко-научни рад Гроздане Олујић предодредио је њено даље усавршавање на плану тематике и израза као и обликовање њеног књижевног пута.

\subsection{0. Нова шанса романа}

11. априла 1957. у 56. броју Младе културе Гроздана Олујић се поново налази у улози новинара чији је задатак вођење књижевног разговара са Радомиром Константиновићем. На врло аутентичан начин, кроз изношење филозофско-поетичких ставова овог аутора, сам дијалог се поставља на пиједестал. Дијалог се посматра као форма над свим формама што Константиновић образлаже следећим речима:

„Пут до одговора је пут кроз алтернативе, сумње, кризе, полемика.Дијалог је огледало и, још више, бог тог путовања. Дефинитивног одговора нема, али је дефинитивна тежња ка њему. Основна форма кроз коју се испољава та тежња је дијалошка форма. Ако је дијалог био само једна од могућности романа верујем да он сада може да се схвати као велики извор и нова шанса романа” (ОЛУЈИЋ 1957: 1).

У књижевним разговорима најмања је могућност проналажења ставова Гроздане Олујић јер се овде јавља само у улози координатора разговора. Међутим, улазећи у суштину самих разговора, откривамо видан утицај искуства, које је током ове врсте ангажовања Гроздана Олујић стекла, и које је важно за њено даље стваралаштво. Стога се према књижевним разговорима односимо као према својеврсној детерминанти 
која усмерава уметничке тенденције и критичко-научне преокупације ове књижевнице.

\subsection{1. Тако сам се родила}

Следећа критика Гроздане Олујић на коју наилазимо у часопису Млада култура посвећена је још једној књижевници. У питању је критика збирке Тако сам се родила Флорике Штефан, која је објављена у 58. броју часописа. Што се саме критике тиче, она се може сврстати у текућу критику, с обзиром на чињеницу да збирка Тако сам се родила излази у Новом Саду 1956. године.

Коментаришући квалитет ове збирке, Олујићева наглашава уметничке вредности које су се мењале кроз развојни пут стваралаштва Флорике Штефан, а у овој збирци оствариле пун потенцијал. Изразито позитиван став који Гроздана Олујић износи о овим песмама поткрепљен је чињеницама да збирка обилује чулношћу, складом и љубављу. Хвали се сензибилитет песникиње која је без „песничких помодности” успела да створи аутономни песнички свет.

У овој критици Гроздана Олујић кроз поређење стваралачког периода појединих писаца са „лепршавим животом воденог цвета” изражава своје схватање о пролазности и трајности уметничких вредности. Говори о разноликости међу припадницима књижевног табора од којих неки, од почетничке фазе, сазревају и долазе до врхунца свог стваралаштва тек након много објављених дела, а неки се јаве једном, али оставе траг који годинама нико не може избрисати. Закључујемо да Гроздана Олујић на аутентичан начин промишља о књижевности и уметничким вредностима, а кроз њено стваралаштво налазимо потврду за то да је она била један од оних писаца који не само да сазрева кроз књижевни рад, већ и кроз књижевнокритичке приказе и есејистичку прозу.

С обзиром на то да се и у овом тексту Олујић бави књижевницом, односно песникињом, потеклом са војвођанског тла, уочавамо у њеном раду својеврсну регионалну оријентисаност и изразит локални патриотизам. Једно од битних обележја Гроздане Олујић као књижевног критичара је да се никада не задржава на површини једног конкретног уметничког текста којим се бави, већ залази у дубинску структуру поетике, као и контекстуалну условљеност, за шта проналазимо доказ и у овој књижевној критици.

\subsection{2. Смисао и льубав}

Критика Смисао и љубав за разлику од свих досадашњих, бави се изношењем става о путопису, али и његовом вредновању. Ова рецензија 
књиге путописа и сусрета Наде Маринковић објављена је, као и претходна, у 58. броју часописа Млада култура који излази 9. маја 1957. године, док је сама књига путописа и сусрета објављена годину дана раније у Загребу. Гроздана Олујић, иако даје назнаку о постојању извесних ситних слабости, позитивно оцењује најновије остварење Наде Маринковић. Проговара о иновацијама у оквиру путописног жанра које ова ауторка уноси у своје дело.

„Нису то путописи у уобичајеном смислу те речи.нигде се не спомиње тај и тај град има толико и толико музеја, тргова, становника, та и та земља толико и толико река, рудника, квадратних метара простора. Па ипак: ако се говори о пролећу на Неви, о московским улицама и предграђима, ми осећамо то свеже и прохладно невско пролеће, ми чујемо тај ужурбан, немиран живот улица и предграђа, ми видимо његове људе" (OLUJIĆ 1957: 4).

Из поменутог цитата закључујемо да Гроздана Олујић примат даје квалитету у односу на квантитет приликом вредновања књижевних текстова уопште. Значајнијим се сматрају поетска структура текста него информације које пуко набрајање административних особина собом носи. Олујићева успоставља везу са дотада написаним делима ове врсте и напомиње да су путописи Наде Маринковић право освежење за нашу књижевну сцену. Дотиче се путописне традиције те набраја најзначајније ауторе ове књижевно-научне врсте.

\subsection{3. Роман Светлане Велмар Јанковић}

Двоброј 60-61 Младе културе који излази 6. јуна 1957. године доноси нам критику прозног рада Светлане Велмар Јанковић, тачније романа Ожиљак који је био номинован за НИН-ову награду. Ово је још једна текућа критика у корпусу текстова Г. Олујић.

Овај кратки приказ има за циљ да у најзначајнијим цртама истакне основне квалитете и одлике романа Светлане Велмар Јанковић. Олујић наглашава да године писца неке књиге не одређују њен квалитет и значај. Тиме она наглашава успех ове младе књижевнице чија је књига номинована за једну од најпрестижнијих књижевних награда у Србији када је она имала свега 23 године. Истичући иновативност коју ова изузетно талентована млада списатељица својим романом доноси у књижевност, Гроздана Олујић наводи три суштинске предности. То су: нови мотиви, другачији начин решавања животних проблема ликова романа, као и сама техника писања. Такође, хвали оригиналност стила изражавања и говори о језику овог романа сагледавајући његов поетски аспект: „Језик којим живи ова књига, једноставан је, дубоко људски и отуда мо- 
жда онај призвук поетског, туге и једне сетне радости да концентрични кругови самоће кад се додирну губе укус и боју самотности и постају мост за разумевање међу људима" (OLUJIĆ 1957: 3).

У рецензији прозе Светлане Велмар Јанковић проналазимо нацрте критеријума којима се Г. Олујић водила при вредновању и оцењивању књижевних дела. Као полазиште сваког успелог књижевног подухвата Гроздана Олујић узима иновативност у грађењу ликова, у мотивационој структури текста и техници писања, као и оригиналност тема и поетско обликовање језика. С обзиром на чињеницу да је Светлана Велмар Јанковић испоштовала све критичке захтеве за које се Олујићева залаже, ова критика садржи елементе панегирика.

\section{4. Језик и стил Гроздане Олујић као књижевног критичара}

Када посматрамо Гроздану Олујић кроз аспект научне сфере њеног рада уочавамо извесно прожимање њеног поетског и књижевнокритичког стила. Доминанту црту њеног стваралаштва чини сагледавање живота кроз призму емоција и духовних вредности што стилу њеног писања даје емоционалну, субјективну ноту. Непристрасност и објективност Гроздане Олујић као критичара се самим проучавањем језика њених критика могу довести у питање. Језик њених књижевнокритичких текстова је књижевно-уметнички и обилује стилским фигурама, фразеологизмима, неологизмима, као и многобројним стилемама (фоностилемама, морфостилемама и синтаксостилемама). Кроз експресивну обојеност израза изражава се емоционални набој који оплемењује стваралачки књижевнокритички рад ове списатељице. Стил којим се Гроздана Олујић користи представља неку врсту негодовања према штурој и објективној рационализацији књижевно-уметничких текстова и осликава њену несакривену тежњу да емотивни сегмент буде важан чинилац при вредновању како поезије тако и прозе. Њене критике представљају један вид минијатурног књижевног дела које карактерише научни карактер, али и поетизован језик и стил.

Будући да говоримо о самим критичким почецима Гроздане Олујић, и узимајући у обзир чињеницу да су проучавани текстови са самог почетка њеног стварања, док још увек није била остварена као писац, можемо закључити да се млада књижевница добро сналазила у неоткривеним круговима књижевно-научних остварења.

Књижевнокритички текстови Гроздане Олујић представљају праву ризницу кроз коју се може сагледати видни напредак и сазревање младе књижевнице као новоафирмисаног аутора и потенцијалног критичара књижевности. У каснијим бројевима часописа Гроздана Олујић донекле мења приступ и, иако задржава најтипичније карактеристике 
писања, њени текстови постају богатији за једну објективнију перспективу проучавања књижевних дела.

На појединим местима, пре свега у домену проучавања интервјуа које је водила Гроздана Олујић са другим писцима, уочавамо изразито оштре скокове од објективности до поетског погледа на свет и уметничких приповедних поступака. Ово можемо поткрепити наведеним цитатом из књижевног разговора са Исидором Секулић где, након постављених питања везаних за књижевност, која представљају сегмент правог научног интервјуа, Гроздана Олујић (1955: 1) завршава поетичким фрагментом:

„Док се напољу згушњава прохладна тама јесењег сутона а у соби, где ми се чини да су на полицама наслагане читаве цивилизације, мелодично избија старински сат подсећајући да је још један делић времена неповратно побегао од нас, опраштам се од жене чије су мисли и дела посејале много добрих жетава... Неколико кратких речи које пажљиво упућују низ стрме степенице. Чврст стисак руке. Једно „довиђења”. И врата се затварају одводећи је поново њеним пријатељима којих има на хиљаде, њеној самоћи и њеном раду” (OLUJIĆ 1955: 1).

Тумачећи овакве сегменте који су честа појава у критичком раду Гроздане Олујић, закључујемо да је она, пре свега, талентована књижевница, чији уметнички дар извире на површину и када пише другачију врсту прозе - књижевно-научне текстове.

\section{5. Закључак: методолошко-критички ставови и критеријуми} вредновања књижевних дела у критичком раду Гроздане Олујић

Књижевну проблематику Гроздана Олујић понекад доживљава исувише лично те тако долази у ситуацију да јој сопствени животни ставови и промишљања директно утичу на систем вредновања и оцењивања књижевног дела. Залаже се за позитивну усмереност идеја које прожимају књижевна дела, као и за оптимизам у књижевности.

Проучавајући савремену књижевност свога доба, стране и домаће ауторе, афирмисане писце и младе таленте који су тек на почетку своје литерарне каријере, Гроздана Олујић изградила је сопствени методолошко-теоријски систем тумачења и процењивања књижевних дела. Са становишта критеријума који су били од пресудног значаја при интерпретацији и вредновању књижевно-уметничких дела, уочавамо неколико основних праваца.

Када говори о послератној књижевности, Гроздана Олујић упућује оштру критику свим писцима који су приказивали песимистичке визије стварности. Залаже се за одређени вид ангажоване књижевности 
и истиче њену неопходност у датом историјско-политичком тренутку, те велича стоицизам и оптимистичко виђење света у литератури. Сматра да књижевност мора бити подстрек, средство за подизање свести и бодрење духа народа који је уточиште изгубио у вртлогу реалности, а може га пронаћи једино уз праву надахнуту уметност речи. У овом смислу може се пронаћи веза између критичких начела Гроздане Олујић и Јована Скерлића, који се може посматрати као књижевнокритички узор, на чије се критеријуме Олујићева повремено ослањала.

На плану тематике, Гроздана Олујић високо је рангирала универзалност, општечовечност, свевременост и актуелност књижевних тема. Такође, стављала је акценат на значај разноврсности и иновативности тема, сматрајући да одабиром великих, вечитих, општељудских тема, писац мора да превазиђе све до тада постављене критеријуме својих књижевних предака како би могао да се истакне и остави траг у историји.

При анализи језика, ограничавала се на његову функцију, и то превасходно поетску, занемарујући семантичко-морфолошки аспекат језичке организације текста. Тезе о језику које прожимају критичке погледе Гроздане Олујић своде се на истицање стилског сегмента, коришћење стилских фигура и онеобичавање језика у виду стилема.

У огледима о поезији, наглашавала је значај ритмичности и „фактуре стиха” која мора бити у служби милозвучности лиричних тонова песама. Била је против прозаизације лирике, сматрајући да свако нарушавање ритмичности, руши целокупну вредност песме.

Јављају се и наговештаји наклоњености „женском писању”, при тумачењу литературе књижевница 20. века. Такође, запажамо и извесну регионалну оријентисаност, те је доза субјективности у вредновању уочљива код писања о војвођанској литератури и писцима тога поднебља. Узимајући све у обзир, можемо закључити да, иако тежи да сагледа књижевна дела са различитих аспеката и тиме обезбеди емоционалну ограђеност и научну објективност, Гроздана Олујић инклинира импресионистичкој критици кроз целокупан стваралачко-критички рад у часопису Млада култура.

\section{Цитирана литература}

OLUJIĆ, 1955: OLUJIĆ, Grozdana. „Moja Afrika”. Mlada kultura, br. 34, god. IV, Beograd: Novinsko izdavačko preduzeće „Omladina”: 1955: 6. [orig.] ОЛУJИЋ, Гроздана. „Моја Африка”. Млада култура, бр. 34, год. IV, Београд: Новинско издавачко предузеће „Омладина”: 1955: 6.

OLUJIĆ, 1955: OLUJIĆ, Grozdana. „Dobar dan tugo”. Mlada kultura, br. 34, god.

IV, Beograd: Novinsko izdavačko preduzeće „Omladina”: 1955: 6. [orig.] ОЛУЈИЋ, Гроздана. „Добар дан туго”. Млада култура, бр. 34, год. IV, 
Београд: Новинско издавачко предузеће „Омладина”: 1955: 6.

OLUJIĆ, 1955: OLUJIĆ, Grozdana. „Fatamorgana”. Mlada kultura, br. 34, god. IV, Beograd: Novinsko izdavačko preduzeće „Omladina”: 1955: 4. [orig.] ОЛУJИЋ, Гроздана „Фатаморгана”. Млада култура, бр. 34, год. IV, Београд: Новинско издавачко предузеће „Омладина”: 1955: 4.

OLUJIĆ, 1955: OLUJIĆ, Grozdana. „Rad, samoće i ćutanja”. Mlada kultura, br. 36, god. IV, Beograd: Novinsko izdavačko preduzeće „Omladina”: 1955: 1. [orig.] ОЛУЈИЋ, Гроздана. „Рад, самоће и ћутања”. Млада култура, бр. 36, год. IV, Београд: Новинско издавачко предузеће „Омладина”: 1955: 1.

OLUJIĆ, 1955: OLUJIĆ, Grozdana. „Primorsko proleće”. Mlada kultura, br.37, god. IV, Beograd: Novinsko izdavačko preduzeće „Omladina”: 1955: 2. [orig.] ОЛУЈИЋ, Гроздана. „Приморско пролеће”. Млада култура, бр.37, год. IV, Београд: Новинско издавачко предузеће „Омладина”: 1955: 2.

OLUJIĆ, 1955: OLUJIĆ, Grozdana. „Bačka zapevka”. Mlada kultura, br. 37, god. IV, Beograd: Novinsko izdavačko preduzeće „Omladina”: 1955: 6. [orig.] ОЛУJИЋ, Гроздана. „Бачка запевка”. Млада култура, бр. 37, год. IV, Београд: Новинско издавачко предузеће „Омладина”: 1955: 6.

OLUJIĆ, 1955: OLUJIĆ, Grozdana. „Strah i čovečnost”. Mlada kultura, br. 42-43, god. V, Beograd: Novinsko izdavačko preduzeće „Omladina”: 1956: 5. [orig.] ОЛУЈИЋ, Гроздана. „Страх и човечност”. Млада култура, бр. 42-43, год. V, Београд: Новинско издавачко предузеће „Омладина”: 1956: 5.

OLUJIĆ, 1955: OLUJIĆ, Grozdana. „Poezija svakidašnjice”. Mlada kultura, br. 45, god. V, Beograd: Novinsko izdavačko preduzeće „Omladina”: 1956: 6. [orig.] ОЛУЈИЋ, Гроздана. „Поезија свакидашњице”. Млада култура, бр. 45, год. V, Београд: Новинско издавачко предузеће „Омладина”: 1956: 6.

OLUJIĆ, 1955: OLUJIĆ, Grozdana. „Ptice bez jata”. Mlada kultura, br. 45, god. V, Beograd: Novinsko izdavačko preduzeće „Omladina”: 1956: 6. [orig.] ОЛУЈИЋ, Гроздана. „Птице без јата”. Млада култура, бр. 45, год. V, Београд: Новинско издавачко предузеће „Омладина”: 1956: 6.

OLUJIĆ, 1955: OLUJIĆ, Grozdana. „Večita svežina sveta”. Mlada kultura, br. 49-50, god. V, Beograd: Novinsko izdavačko preduzeće „Omladina”: 1956: 2. [orig.] ОЛУЈИЋ, Гроздана. „Вечита свежина света”. Млада култура, 6р. 49-50, год. V, Београд: Новинско издавачко предузеће „Омладина”: 1956: 2.

OLUJIĆ, 1955: OLUJIĆ, Grozdana. „Nova zbirka pesama Branka V. Radičevića”. Mlada kultura, br. 52, god. VI, Beograd: Novinsko izdavačko preduzeće „Omladina”: 1957: 4. [orig.] ОЛУЈИЋ, Гроздана., „Нова збирка песама Бранка В. Радичевића”. Млада култура, бр. 52, год. VI, Београд: Новинско издавачко предузеће „Омладина”: 1957: 4.

OLUJIĆ, 1955: OLUJIĆ, Grozdana. „Nova šansa romana”. Mlada kultura, br. 56, god. VI, Beograd: Novinsko izdavačko preduzeće „Omladina”: 1957: 1. [orig.] ОЛУЈИЋ, Гроздана. „Нова шанса романа”. Млада култура, бр. 56, год. VI, Београд: Новинско издавачко предузеће „Омладина”: 1957: 1.

OLUJIĆ, 1955: OLUJIĆ, Grozdana. „Tako sam se rodila”. Mlada kultura, br. 58, god. VI, Beograd: Novinsko izdavačko preduzeće „Omladina”: 1957: 4. [orig.] 
ОЛУЈИЋ, Гроздана. „Тако сам се родила”. Млада култура, бр. 58, год. VI, Београд: Новинско издавачко предузеће „Омладина”: 1957: 4.

OLUJIĆ, 1955: OLUJIĆ, Grozdana. „Smisao i ljubav”, Mlada kultura, br. 58, god. VI, Beograd: Novinsko izdavačko preduzeće „Omladina”: 1957: 4. [orig.] ОЛУЈИЋ, Гроздана. „Смисао и љубав”. Млада култура, бр. 58, год. VI, Београд: Новинско издавачко предузеће „Омладина”: 1957: 4.

OLUJIĆ, 1955: OLUJIĆ, Grozdana. „Roman Svetlane Velmar-Janković”. Mlada kultura, br. 60-61, god. VI, Beograd: Novinsko izdavačko preduzeće „Omladina”: 1957: 3. [orig.] ОЛУЈИЋ, Гроздана. „Роман Светлане Велмар-Јанковић”. Млада култура, бр. 60-61, год. VI, Београд: Новинско издавачко предузеће „Омладина”: 1957: 3.

POPOVIĆ, 2007: T. Popović. Rečnik književnih termina. Beograd: Logos art, 2007. ПОПОВИЋ, Тања. Речник књижевних термина. Београд: Логос арт, 2007.

ŽIVKOVIĆ, 1986: D. Živković. Rečnik književnih termina. Beograd: Nolit, 1986. ЖИВКОВИЋ, Драгиша. Речник књижевних термина. Београд: Нолит, 1986.

Katarina Milenković

Aleksandra Pejić

\section{GROZDANA OLUJIĆ'S CRITICAL BEGINNINGS IN THE MAGAZINE MLADA KULTURA}

The aim of this paper is to analyze the insufficiently researched field of work of Grozdana Olujić, which refers to her first achievements in literary criticism. Her first essay and literary critical texts were published in the magazine Mlada Kultura, which was issued in the period from November 13th, 1952 to June 6, 1957. Our paper deals with this author's initial works of literary criticism published in the above-mentioned magazine, which she wrote when she was around the age of twenty. Grozdana Olujić was inclined towards impressionistic criticism throughout her entire creative-critical work in the magazine Mlada Kultura. The paper follows the work of Grozdana Olujić as a literary critic, as well as the influence that the magazine Mlada Kultura had on the formation of her methodological and critical attitudes.

Keywords: Grozdana Olujić, literary criticism, essay, magazine Mlada Kultura 